\title{
Use of sex pheromones in faunistic research on Synanthedon scoliaeformis (Lepidoptera, Sesiidae) in Poland
}

\author{
Marek BĄKOWSKI \\ Department of Systematic Zoology, Institute of Environmental Biology, A. Mickiewicz University, \\ Umultowska 89,61-614Poznań, e-mail: bakowski@amu.edu.pl
}

\begin{abstract}
Studies on the distribution of Synanthedon scoliaeformis were carried out in western, south-western and south-eastern Poland by means of synthetic sex attractants. Funnel traps baited mainly with one component E2,Z1318:Ac, were used. This study confirms that the use of sex attractant is highly efficient in faunistic studies and pheromone trapping may offer a user friendly and reliable method for monitoring this rare clearwing moth species which otherwise are hard to detect. New records and all the literature data on S. scoliaeformis, caught in Poland with the help of sex pheromone are presented.
\end{abstract}

Key words: Synanthedon scoliaeformis, Sesiidae, sex attractants, distribution, faunistic, Poland

\section{INTRODUCTION}

The Welsh clearwing Synanthedon scoliaeformis (Borkhausen 1789) is one of the most beautiful and largest species of clearwing moths in Europe. The characteristic feature of this moth is the usually rusty an anal tuft. The larva lives two or three years between bark and wood of sunlit birch tree trunks (Betula spp.. Betulacae).

S. scoliaeformis has a Eurasian distribution (Laštùvka \& Laštůvka 2001). It occurs in northern and central Europe, in Ireland. Britain. Scandinavia and northern Russia extending beyond the Arctic Circle (Špatenka et al. 1999). The southern range limit runs through northern Spain and northern Italy and coincides with the distribution of the host plant. The species also occurs in southern Romania, Bulgaria, the temperate zone of European Russia, Ukraine, the central Caucasus, the Urals, throughout western Siberia, the Altai Mountains, Transbaikal, Georgia, Uzbekistan, northern and western Kazakhstan, central Mongolia. the Russian Far East. China and Japan (Špatenka et al. 1999).

In Poland S. scoliaeformis has been reported from the most provinces (Bakowski 2000). Probably, it is widespread, but usually rare and mainly recorded individually (Schnaider et al. 1961). Despite several studies on clearwing moths in various regions of Poland in the past 20 years, the species has been reported mainly on the basis of old exit holes (Bakowski 1992) or single reared adults (Bakowski 2001. Bąkowski et al. 2003. Śliwiński \& Kowalczyk 1995). Most of larvae and pupae of this species have been collected only in Polesie Lubelskie region (Bąkowski \& Holowiński 1997).

The objective of this studies was to show how sex pheromones can be used in faunistic studies on $S$. scoliaeformis and other clearwing species in Poland and Europe.

\section{METHODS}

Funnel traps (Uni-Trap) were used and loaded with commercial insects poison, a plate saturated with dichlorvos. The traps were baited with either one of two commercial lures prepared at the Plant Research International (PRI) in Wageningen (the Netherdands). One of 
them designed for Synanthedon scoliaeformis (SCOLIA-PRI) and the second one was intended for Synanthedon tipuliformis Cl. (TIP-PRI). Some traps were baited with a mixture of E2,Z1318:Ac (TIP-UAS) prepared in University of Agricultural Science (UAS) in Alnarp, Sweden, supplied by Dr M. Larsson (UAS).

In the field the traps were fixed to tree branches (most often birch trees), approximately 1.5 $\mathrm{m}$. above the ground in sunny places (Bakowski 2002 a). In each locality one or two traps were placed. They were inspected once per 1 week. In several cases males of S. scoliaeformis were observed and caught flying near the attractant. All pheromones used in this study contained the compound E2,Z13-18:Ac. As expected all collected specimens were males. In the case where names of collector were not given, the moths were recorded by the author.

\section{RESULTS}

\section{Records of $S$. scoliaeformis caught in Poland with help of sex pheromone}

\section{Dolny Śląsk Province}

Literature data:Tomisław (UTM: WS28) and Olotok (WS28) - the Bory Dolnośląskie, in total 60 exx. on pheromone (SCOLIA-PRI), in 2005-2006, mainly $25 \mathrm{VI}-15 \mathrm{VII}$ leg. A. Hyjek, between 10 a.m. and 5 p.m., peak of the activity 10 a.m. - 2 p.m. (Kokot 2007); Piekielna Góra ad Polanica Zdrój (XR08), 8-9 VI 2007, 8 exx., pheromone (TIP-UAS), 8 VI 2007. 3 exx., pheromone (TIP-UAS), 1 ex. pheromone (SCOLIA-PRI); Szczeliniec (WR99), 10 VI 2007, the visual observations of 5 males flight to pheromone (TIP-UAS), 11.30-12 a.m.; Polanica Zdrój-Park, (XR08), 9-10 VI 2007, 1 ex., pheromone (TIP-UAS) (Bąkowski 2009).

New data: Grodziec Śląski (CA41), 4 VII 2009, 4 exx. collected flying near pheromone (SCOLIA-PRI); Tomislaw (WS28), 24-26 VI 2008, 6 exx. collected near pheromone (SCOLIA-PRI), leg. X. Dobrzański.

Wielkopolska Province

Literature data: Rogalin (XT38), 20-27 V 2007, 15 exx., pheromone (TIP-UAS); $25 \mathrm{~V}-$ 15 VI 2009, 14 exx., pheromone (SCOLIA-PRI); 30 VI - 20 VII 2009, 17 exx., pheromone (TIP-UAS) (Bąkowski 2011).

New data: Bolechowo (XU32), 9-10 VI 2009, 5 exx., pheromone (TIP-UAS); 1620 VI 2009, 11 exx., pheromone (TIP-UAS); 2-5 VII 2009, 7 exx., pheromone (TIP-UAS), leg. W. Śliwa; Res. Morasko (XU22), 18-19 VI 2008, 5 exx., pheromone (TIP-UAS); Suchy Las - the buffer zone of the military area (XU21), 3-9 VII 2009, 2 exx., pheromone (TIPUAS); 10 VI - 2 VII 2010, 6 exx., pheromone (TIP-UAS), Wielkopolski National Park, on route from Trzebaw to Puszczykówko (XT29), 20 VI - 6 VII 2009, 5 exx., pheromone (SCOLIA-PRI); Poznań - Koszalińska (XU21), 13-21 VI 2010, 33 exx., pheromone (TIPUAS), Poznań - Biskupińska (XU21), 13-21 VI 2010, 5 exx., pheromone (TIP-UAS); 1 ex., pheromone (TIP-PRI); Poznań - Marcelin (XU20), 20 VI - 6 VII 2010, 24 exx., pheromone (TIP-UAS); Rogalin (XT38), 20 VI - 6 VII 2010, 25 exx., pheromone (TIP-UAS).

Lublin Province

New data: Macoszyn (FB79), 6-10 VI 2009, 30 exx., pheromone (SCOLIA-PRI).

\section{Discussion}

Voerman et al. (1984) found that the compound E2,Z13-18:Ac attracted males of currant borer (S. tipuliformis). Field screening has shown that this compound attracts also males of S. scoliaeformis (Buda et al. 1993; Pühringer 1998). This study has confirmed that a mixture of 
the two compounds: A (E2,Z13-18:Ac) and B (Z3,Z13-18:Ac) in a ratio 100:1 is highly attractive to males of $S$. scoliaeformis. This blend was identified by Priesner and Ryrholm and since then it has been known as the Priesner's pheromone 19 (Pühringer 1996, Pühringer \& Ryrholm 2000). The blend of the commercial lure designed for $S$. scoliaeformis in Wageningen (SCOL-PRI) is based of Priesner's pheromone 19 (Pherobank-PRI). The study of sex pheromones of Sesiidae showed that, apart from identification of the chemical composition of pheromones of individual species, the study of ethology, in particular related to daily sexual activity, has become a new stage in investigation of the speciation process of these clearwing moths.

Kokot (2007) indicated that the males of S. scoliaeformis coming to pheromones between $10 \mathrm{a} . \mathrm{m}$. and 5 p.m., and the peak of daily activity was between $10 \mathrm{a} . \mathrm{m}$. and $2 \mathrm{p} . \mathrm{m}$. The author's field studies were based mainly on using traps, but a few direct observations of flying males suggested that the peak of daily sexual activity was between 10 and 12 a.m., what corroborates the observations by Kokot. It remains in accordance with data published by Pühringer \& Ryrholm (2000) and Bakowski (2002 b).

This study confirms that the use of more or less species specific sex attractants is an effective method of monitoring of this rare and local clearwing species. In many cases the males of $S$. scoliaeformis were attracted to pheromones traps in great numbers. Previously, the species has been reported in the study areas, mainly on the basis of old exit holes or single reared adults.

Since the sex pheromones attracts only males, it does not cause any damage to the populations of the target species - the females will be mated by other males. This method is thus well suited for faunistic studies and enables recording of species which have low densities and which cannot be easily detected by others methods.

The clearwing moths includes a number of bigger and more mobile xylophagous species as: Paranthene insolita (Sobczyk 1995; Bąkowski et al. 2009), Synanthedon conopiformis (Bakowski 1998), S. andrenaeformis (Bakowski et al. 2008), S. mesiaeformis (Bakowski \& Ryrholm 2003, Karalius \& Buda 2006), S. soffneri (Priesner 1993, Pühringer \& Scheuchenpflug 1995) which all can be surveyed by the aid of sexual attractants. However, the best results are obtained when using the combination of both method - the use of sex pheromones and the search of preimaginal stages. In the case of $S$. scoliaeformis it is possible to detect the presence of the species based on their characteristic old exit holes with the rests of cocoons. The sun parts of birches should be carefully inspected for the presence of ca. $5 \mathrm{~mm}$ round old exit holes typical of that species, usually with the remains of characteristic long and prim cocoons inside the burrows. These old exit holes remain for several years as a sign of previous infestation by the species (Predovnik 2008).

\section{ACKNOWLEDGEMENTS}

I would like to express my cordial thanks to X. Dobrzański and W. Śliwa for providing faunistic data and help in field research. I thank Dr M. Larsson (University of Agricultural Science, Alnarp, Sweden (UAS) for providing some of the attractants and Dr N. Ryrholm (University of Gävle, Sweden) for his linguistic help and suggestion regarding the manuscript.

\section{REFERENCES}

BÁKOWSKI M. 1992. Przezierniki (Lepidoptera, Sesiidae) miasta Poznania i okolic. Wiadomości Entomologiczne 11, 3: $169-173$.

BAKOWSKI M. 1998. Zastosowanie pulapek feromonowych w badaniach rozmieszczenia Synanthedon conopiformis (Esper, 1782) (Lepidoptera, Sesiidae) w Polsce. Przegląd Przyrodniczy 9, 3: 8-11.

BÁKOWSKI M. 2000. Sesiidae. In: Buszko J. \& NowAcki J. (eds), The Lepidoptera of Poland. A Distributional Checklist, pp.52-53. Polish Entomological Monographs, 1, 178 pp.

BĄKOWSKI M. 2001. Przezierniki (Lepidoptera: Sesiidae) Zespołu Parków Krajobrazowych Ponidzia. Roczniki Naukowe Polskiego Towarzystwa Ochrony Przyrody "Salamandra " 5: 79-95. 
BĄKOWSKI M. 2002a. Zastosowanie atraktantów pleiowych w badaniach faunistycznych przezierników (Lepidoptera: Sesiidae). Wiadomości Entomologiczne 20 (3-4): 165-170.

BAKOWSKI M. 2002b. Daily activity patterns of clearwing moth species at pheromone baits in Poland (Lepidoptera: Sesiidae). Biological Letters 39 (1/2): 42-48.

BĄKOWSKI M. 2011. Przezierniki (Lepidoptera, Sesiidae) Rogalińskiego Parku Krajobrazowego. Wiadomości Entomologiczne $30(2): 104-109$.

BĄKOWsKi M. \& Holowiński M. 1997. Przezierniki (Lepidoptera, Sesiidae) południowo-wschodniej części Polesia Lubelskiego. Wiadomości Entomologiczne 16 (2): 107-114.

BĄKOWSKI M., HoŁowIŃSKI M. \& MiŁKOWSKI M. 2003: Przezierniki (Lepidoptera: Sesiidae) Puszezy Kozienickiej Wiadomości Entomologiczne 21, 4: 229-240.

BAKOWSKI M. \& RYRHoLM N. 2003. Synanthedon mesiaeformis (H.-S.) w Puszczy Bialowieskiej. Wiadomości Entomologiczne 21, 4: 252.

BĄKOWSKI M., CELADYN R., HOlOWIŃSKI M. \& ZAJDA W. 2008. Nowe stanowiska Synanthedon andrenaeformis (Laspeyres, 1801) (Lepidoptera, Sesiidae) w Polsce. Wiadomości Entomologiczne 27, 3: 177-178.

BÁKOWSKI M., HolowińSKI M. \& RYRHOLM N. 2009. Paranthrene insolita Le Cerf 1914 (Lepidoptera:Sesiidae) - a new clearwing moth species to the fauna of Poland. Polish Journal of Entomology 78: 115-120.

Buda V., MaEorg U., Karalius V., Rothschild G. H. L., Kolonistova S., IVINSKis P. \& MozURaitis R. 1993. C-18 dienes as attractants for eighteen clearwing (Sesiidae), tineid (Tineidae), and choreutid (Choreutidae) moth species. Journal of Chemical Ecology 19, 4: 799-813.

KARALIUS V. \& BUDA V. 2006. The investigation of Synanthedon mesiaeformis and S. flaviventris (Lepidoptera, Sesiidae) distribution in Lithuania using sex attractants. Acta Zoologica Lituanica 16, 3: 204-209.

KOKOT A. 2007. Badania nad przeziernikami (Lepidoptera: Sesiidae) poludniowo-zachodniej częśsi Polski z zastosowaniem feromonów. Acta entomologica Silesiana 14/15: 39-44.

LAS̆TƯVKa Z. \& LAS̆TU゚VKA A. 2001. The Sesiidae of Europe. Apollo Books Stenstrup, 245 pp.

PREDOVNTK Z. 2008. Synanthedon scoliaeformis (Borkhausen, 1789) (Lepidoptera: Sesiidae) in NE Slovenia and W Hungary. Acta Entomologica Slovenica 16, 2, 137-144.

PRIESNER E. 1993: Pheromontest an einer südbayrischen Population von Synanthedon soffneri Špatenka 1983 (Lepidoptera Sesiidae). Nachrichtenblatt der Bayrischen Entomologen 42, 4: 97-107.

PÜHRTNGER F. 1996. Utilities zum Pheromonfang von Sesien (Lepidoptera, Sesiidae). Entomologisches Nachrichtenblatt (NF) 3,1: 8-12.

PÜHRINGER F. \& RYRHOLM N. 2000. Pheromonanflug europäischer Glasflügler (Lepidoptera, Sesiidae). Mitteilungen der Entomologischen Arbeitsgemeinschaft Salzkammergut 3, 65-72.

PÜHRINGER F. \& SCHEUCHENPFLUG A. 1995. Erstnachweis von Synanthedon soffneri Špatenka 1983 (Heckenkirschenglasflügler) in Oberösterreich (Lepidoptera, Sesiidae). Zeitschrift der Arbeitsgemeinschaft Österreichischer Entomologen 47(3/4), 65-69.

SCHNAIDER J. \& SCHNAIDER Z. 1961. Motyle - Lepidoptera, Przezierniki - Aegeriidae. Klucze do oznaczania owadów Polski 27, 37. PWN, Warszawa, 42 pp.

SOBCZYK T.1995. Wiederfund von Paranthrene insolita Le Cerf, 1914 (Lep., Sesiidae) in Ostdeutschland. Entomologische Nachrichten und Berichte 39, 3, 153.

ŚLIWINSKI Z. \& KOWALCZYK J. K., 1995. Przezierniki (Lepidoptera, Sesiidae) Wyżyny Lódzkiej. Wiadomości Entomologiczne 14, 4: 231-236.

ŠPATENKa Z., GorbUnOV O, LAŠTI゚Vka Z., TOŠEVSKi I. \& ARITA Y. 1999. Sesiidae - Clearwing Moths. Handbook of Palaearctic Macrolepidoptera. Vol.1. GEM Publishing, Wallingford, $569 \mathrm{pp}$.

Voerman S., PERsoons C. \& PrIESNER E. 1984. Sex attractant for currant clearwing moth Synanthedon tipuliformis Cl. (Lep. Sesiidae). Journal of Chemical Ecology 10: 1371-1376.

\section{STRESZCZENIE}

\section{[Wykorzystanie feromonów plciowych w badaniach faunistycznych Synanthedon scoliaeformis (Lepidoptera, Sesiidae) w Polsce]}

Dzięki zastosowaniu pulapek feromonowych stwierdzono nowe stanowiska Synanthedon scoliaeformis w zachodniej, południowo-zachodniej i wschodniej części kraju. Zastosowano głównie pułapki typu uni-trap zaopatrzone w związek E2,Z13-18:Ac. Badania terenowe potwierdzily dużą skuteczność pułapek feromonowych w badaniach faunistycznych. Jest to skuteczna i mało inwazyjna metoda stwierdzania wielu gatunków Sesiidae, których pozyskiwanie innymi metodami jest trudne. 